\title{
PENINGKATAN KEMAMPUAN BERPIKIR KREATIF PESERTA DIDIK MELALUI PENERAPAN MODEL PROBLEM BASED LEARNING PADA PELAJARAN IPA KELAS VII
}

\author{
Lailatur Rohmah \\ MTsN 5 Kediri \\ lailaturrohmah23@gmail.com
}

\begin{abstract}
This study aims to improve students' creative thinking skills in science lessons by applying learning models using Problem Based Learning. The research subjects were 32 students in class VII G. The classroom action research was conducted in three cycles. Each cycle consists of four stages of activity, including planning, implementation, observation, and reflection. Written tests and questionnaires are used to measure creative thinking skills of cognitive and affective aspects. The results of the study were analyzed using descriptive percentage analysis and n-gain test to determine the increase in research results. Based on the results of the analysis, it is known that students' creative thinking abilities increased accompanied by an increase in classical learning completeness. The average percentage of creative thinking ability in the first cycle was $74.4 \%$, the second cycle was $77.7 \%$, and the third cycle was $81.5 \%$. The percentage of completeness in the second cycle increased $9.4 \%$ and the third cycle increased $3.1 \%$ with the criteria of a low increase. It can be concluded that the Problem Based Learning model is able to improve the creative thinking skills of class VII G students in MTsN 5 Kediri.

Keywords: Problem Based Learning, the increase of creative thinking skill, science lessons.
\end{abstract}

\begin{abstract}
Abstrak: Penelitian ini bertujuan untuk meningkatkan kemampuan berpikir kreatif peserta didik pada pelajaran IPA dengan menerapkan model pembelajaran Problem Based Learning. Subyek penelitian yaitu 32 peserta didik kelas VII G. Penelitian tindakan kelas ini dilaksanakan tiga siklus. Tiap siklus terdiri dari empat tahap kegiatan, yaitu perencanaan, pelaksanaan, pengamatan, dan refleksi. Tes tertulis dan angket digunakan untuk mengukur kemampuan berpikir kreatif aspek kognitif dan afektif. Hasil penelitian dianalisis menggunakan analisis deskriptif persentase dan uji n-gain untuk mengetahui peningkatan hasil penelitian. Berdasarkan hasil analisis diketahui bahwa kemampuan berpikir kreatif peserta didik meningkat diiringi peningkatan ketuntasan belajar klasikal. Rata-rata persentase kemampuan berpikir kreatif pada siklus I sebesar 74,4\%, siklus II 77,7\%, dan siklus III $81,5 \%$. Persentase ketuntasan pada siklus II meningkat 9,4\% dan siklus III meningkat $3,1 \%$ dengan kriteria peningkatan rendah. Dapat disimpulkan bahwa model pembelajaran Problem Based Learning mampu meningkatkan kemampuan berpikir kreatif peserta didik kelas VII G di MTsN 5 Kediri.
\end{abstract}

Kata Kunci: Problem Based Learning, peningkatan kemampuan berpikir kreatif, pelajaran IPA 


\section{Pendahuluan}

IPA sebagai cabang pengetahuan yang erat kaitannya dalam usahan menemukan alam dengan teratur, sehingga penguasaan IPA tidak lain dari konsep, prinsip dan fakta saja tetapi menemukan yang diperoleh melalui praktik langsung. Pendidikan IPA fokus pada memberikan pengalaman secara langsung demi mencapai kompetensi agar peserta didik dapat mengetahui dan menelaah secara benar benar tentang lingkungan alam lebih mendalam. Oleh karena itu, proses pembelajaran IPA lebih mengutamakan pengalaman perseorangan melalui proses pengamatan, pertanyaan, penalaran, dan percobaan untuk meningkatkan daya cipta (kemampuan mencipta) peserta didik (Trianto, 2007). Menurut Munandar (2009), daya cipta menjadi penting untuk berhasil dan tumbuhnya pribadi serta mempunyai peran dalam membangun Indonesia, sehingga peserta didik perlu ditingkatkan kreativitasnya. Observasi di kelas VII di MTsN 5 Kediri diperoleh hasil pada proses pengerjaan soal sebagian besar peserta didik terhadap masalah IPA yang diberikan guru dapat diselesaikan dengan memakai cara yang seperti dicontohkan oleh guru. Masalah IPA yang dihadapi siswa dibuat berlainan dalam menyajikannya seperti tingkat kesulitan yang bisa dikerjakan dengan berbagai cara, peserta didik merasakan sukar dalam menyelesaikan masalah tersebut. Hal ini disebabkan cara berpikir peserta didik masih konvergen. Peserta didik belum biasa dalam berpikir secara divergen. Untuk mengatasi masalah-masalah tersebut, perlu dilakukan pembelajaran IPA dengan cara berpikir kreatif peserta didik untuk menyelesaikan permasalahan dalam belajar. Pemilihan model pembelajaran yang tepat menjadi pilihan agar masalah tersebut terselesaikan. Sebagian model pembelajaran menggunakan model Problem Based Learning (PBL) diharapkan kemampuan berpikir kreatif peserta didik meningkat. Penggunaan model pembelajaran yang tepat bagi peserta didik akan mampu membangkitkan kemampuan berpikir kreatif peserta didik.

Bersumber dari uraian di atas, masalah penelitian difokuskan pada menerapkan model pembelajaran $P B L$ dalam peningkatan kemampuan berpikir kreatif peserta didik. Tujuannya untuk mengetahui peningkatan kemampuan berpikir kreatif peserta didik pada pelajaran IPA di MTsN 5 Kediri melalui penerapan model pembelajaran $P B L$.

Memberlajarkan IPA di sekolah sebaiknya lebih menegaskan pada pengalaman yang diberikan secara langsung untuk mencapai kompetensi peserta didik, agar peserta didik lebih paham tentang alam sekitar dengan proses mencari keterangan dan melakukan sesuatu. Peserta didik akan terbantu dalam memahami yang ia peroleh secara mendalam. Keterampilan proses dapat dicapai melalui nilai sikap seperti kritis, cermat, jujur, tekun, rasa ingin tahu, ulet, disiplin, sabar, peduli dan terbuka terhadap lingkungan (Trianto, 2007).

Barrow memaknai $P B L$ sebagai pembelajaran berbasis masalah yang memperoleh pembelajaran menempuh proses resolusi terhadap masalah untuk memperoleh suatu pemahaman. Esensi dari pembelajaran berbasis masalah menurut Arends (2007) berupa autentiknya masalah yang muncuk dan memiliki kemaknaan agar memotivasi peserta didik dalam menginvestigasi, menyelidiki dan mengembangkan kemampuan intelektualnya. Sintak model pembelajaran berbasis masalah 
menurut Arends terdiri atas 5 tahap. Tahapan tersebut yaitu: (1) orientasi masalah yang dilakukan peserta didik, (2) pengorganisasian belajar, (3) pembimbingan kegiatan penyelidikan secara individu dan kelompok, (4) peserta didik melakukan aktivitas pengembangan dan penyajian hasil karyanya, dan (5) peserta didik melalukan analisis dan evaluasi dalam memecahkan masalah.

Menurut Chandra dalam Irham dan Wiyani (2013), istilah kreativitas merupakan sebuah bentuk kemampuan mental ada pada personal orang untuk meghasilkan dan mengungkapkan sesuatu yang berbeda dan unik dari halhal secara tepat sasaran, orisinalitas, efisien, baru, indah, serta tepat guna. Menurut Irham dan Wiyani (2013), proses berpikir kreatif pada seseorang atau peserta didik akan dapat dicirikan dan dapat dilihat dari hasilnya.

\section{Metode}

Subyek penelitian yaitu peserta didik kelas VII semester genap tahun akademik 2019/2020 di MTsN 5 Kediri yaitu kelas VII G dengan jumlah sampel penelitian 32 orang peserta didik. Sumber data diperlukan untuk mengetahui dari mana data dalam penelitian ini diperoleh pada suatu penelitian. Data penelitian terdiri dari daftar nama peserta didik, nilai tes pada pertemuan sebelum pelaksanaan PTK (pra siklus), perangkat pembelajaran, foto-foto maupun video pembelajaran IPA. Metode pengumpulan data menggunakan tes (soal pilihan ganda) serta non tes (angket). Data yang diperoleh juga dilakukan analisis data tes evaluasi pengetahuan dan angket kemampuan berpikir kreatif. Untuk menganalisis data tersebut maka dilakukan deskriptif persentase serta uji n-gain. Keberhasilan penelitian jika telah sesuai dengan indikator yaitu: (1)
Ketuntasan klasikal hasil belajar aspek kognitif peserta didik mencapai $\geq 80 \%$ dari jumlah peserta didik dalam kelas dan (2) Kreatifitas berpikir peserta didik dikatakan berhasil dalam penelitian apabila kemampuan berpikir kreatif mencapai persentase $\geq 75 \%$. Langkah kegiatan pada penelitian antara lain merencanakan, melaksanakan, mengamati dan merefleksi. Penelitian dilaksanakan sejumlah 3 siklus dengan setiap siklus terdiri dari 2 kali pertemuan.

\section{Hasil dan Pembahasan}

Siklus I diperoleh hasil kegiatan pembelajaran belum mencapai target kemampuan berpikir kreatif $\geq 75 \%$, yaitu sudah mencapai rata-rata $74,4 \%$ dan mencapai hasil belajar $\geq 80 \%$, yaitu sudah mencapai rata-rata $8 \overline{1}, 3 \%$. Hasil penelitian yang telah mencapai indikator keberhasilan hanya salah satu aspek saja, sehingga perlu dilakukan penelitian lebih lanjut. Maka disusunlah rencana pembelajaran pada siklus II dengan memperbaiki kinerja guru dalam pelaksanaan pembelajaran. Pada siklus II, penggunaan model $P B L$ telah mencapai target kemampuan berpikir kreatif $\geq 75 \%$, yaitu sudah mencapai rata-rata $77,7 \%$ dan mencapai hasil belajar $\geq 80 \%$, yaitu sudah mencapai rata-rata $90,6 \%$. Hasil penelitian pada siklus II indikator keberhasilan tercapai, namun pada penelitian sebelumnya dikhawatirkan merupakan kebetulan saja hasilnya baik peserta didik bisa memiliki kemampuan berpikir kreatif melalui model $P B L$ sehingga karena itu maka disusunlah rencana pembelajaran pada siklus III dengan memperbaiki kinerja guru melaksanakan pembelajaran.

Siklus I, II, dan III pada kelas VII $\mathrm{G}$ dengan menggunakan model $P B L$ menunjukkan peningkatan kemampuan berpikir kreatif peserta didik yang 
diiringi juga peningkatan prestasi belajar peserta didik. Peserta didik MTsN 5 Kediri kelas VII G jika dibelajarkan dengan model $P B L$ diperoleh hasil kemampuan berpikir kreatifnya meningkat. Hal ini dapat dilihat pada siklus I terdiri dari 6 peserta didik belum tuntas belajar secara individu dari 44 peserta didik. Siklus II terdapat 3 peserta didik yang belum tuntas secara individu dari 32 peserta didik. Sedangkan pada siklus III secara individu dari 32 peserta didik hanya 2 orang ketuntantasan belajarnya belum tercapai. Peserta didik yang ketuntasannya belum tercapai di siklus I sejumlah 6 dari 32 peserta didik yang belum tuntas belajar secara individu. Peserta didik yang belum tuntas dikarenakan masih belum menjadi kebiasaan dengan belajar menggunakan metode yang sudah digunakan guru. Selain itu terdapat juga beberapa peserta didik yang belum mengerti atau belum paham dengan pembelajaran pada siklus I.

Prestasi yang didapat peserta didik serta kemampuan berpikir kreatifnya dapat meningkat disebabkan dibelajarkan dengan model $P B L$ yang dianggap efektif digunakan saat pembelajaran sehingga kondisi pembelajaran pun yang dirasa peserta didik tidak membosankan. Untuk lebih jelasnya, berikut rekapitulasi kemampuan berpikir kreatif, ketuntasan belajar klasikal, dan kinerja guru hasil pelaksanaan pembelajaran siklus I, II, dan III.
Tabel 1. Hasil Pembelajaran Siklus I, Siklus II, dan Siklus III

\begin{tabular}{|c|l|c|c|c|}
\hline No & \multicolumn{1}{|c|}{ Faktor } & $\begin{array}{c}\text { Siklus } \\
\text { I }\end{array}$ & $\begin{array}{c}\text { Siklus } \\
\text { II }\end{array}$ & $\begin{array}{c}\text { Siklus } \\
\text { III }\end{array}$ \\
\hline 1 & $\begin{array}{l}\text { Kemampuan } \\
\text { berpikir } \\
\text { kreatif (\%) }\end{array}$ & 74,4 & 77,7 & 81,5 \\
\hline 2 & $\begin{array}{l}\text { Ketuntasan } \\
\text { belajar } \\
\text { klasikal (\%) }\end{array}$ & 81,3 & 90,6 & 93,8 \\
\hline 3 & $\begin{array}{l}\text { Kinerja guru } \\
(\%)\end{array}$ & 93,3 & 95,1 & 97,3 \\
\hline
\end{tabular}

Berdasarkan hasil pembelajaran pada setiap siklus secara keseluruhan, pembelajaran dengan menerapkan model PBL, masalah IPA dapat diselesaikan oleh peserta didik dengan baik. Berdasarkan hasil penelitian yang telah dilakukan, penggunaan model $P B L$ sangat cocok digunakan pada mata pelajaran IPA di MTsN 5 Kediri. Bagan peningkatan kemampuan berpikir kreatif peserta didik dapat dilihat ditunjukkan gambar berikut.

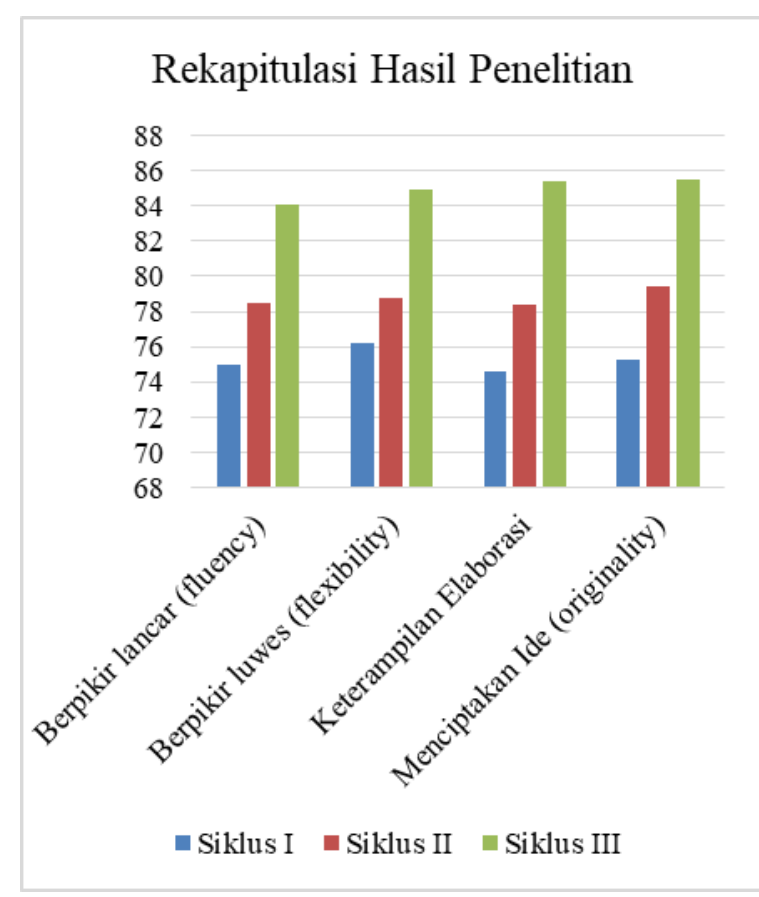

Gambar 1. Rekapitulasi Hasil Penelitian 
Kemampuan berpikir dinyatakan lancar pada siklus I dengan perolehan skor 75 dalam ketercapaian dan keberhasilan indikator. Penyebab kondisi ini adalah peserta didik saat berdiskusi mempunyai cara berpikir yang lain untuk suatu masalah yang harus diselesaikan sehingga diperoleh cara dan jawaban atas hasil diskusi tersebut dalam menyelesaikan masalah; yang artinya kemampuan berpikir peserta didik bersifat divergen. Kemampuan berpikir divergen mampu melatih daya cipta/kreativitas peserta didik. Peningkatan berpikir lancar ini disebabkan melalui diskusi selama pembelajaran maka peserta didik mempunyai kebebasan dalam menyampaikan pendapatnya dan mampu menyelesaikan masalah yang telah ia hadapi.

Kemampuan berpikir peserta didik pada siklus I dapat dikatakan rasional, luwes dan elaboratif meskipun ketercapaian dan keberhasilan indikatornya masih rendah yaitu 76 . Penyebabnya adalah tidak terbiasa dalam berpikir kreatif yang dibelajarkan dengan model $P B L$. Siklus II dan III kemampuan berpikir peserta didik bersifat luwes disebabkan ada kebiasaan pembelajaran melakukan kreatifitasnya dalam berpikir dengan model $P B L$.

Kemampuan elaborasi pada siklus I belum memenuhi indicator keberhasilan. Ketika kegiatan diskusi kelompok, peserta didik dapat aktif dalam pembelajaran dengan saling berpendapat dan kerja sama dalam memecahkan masalah namun terdapat beberpa peserta didik yang masih pasif pembelajarannya pada siklus I. Hal tersebut yang perlu diperhatikan adalah mengaktifan peserta didik dengan memotivasi selama pembelajaran melalui diskusi. Peningkatan pembelajaran siklus II dan III disebabkan kemampuan elaborasinya.
Peserta didik mampu dalam penciptaan ide, hal ini dapat ditelusuri dari peningkatan nilai untuk siklus I hingga siklus II dengan nilai yang sangat kecil untuk siklus II ke siklus III. Adanya keterbiasaan peserta didik ketika harus menyelesaikan masalah menggunakan logika berpikirnya dan telah tepat dengan teori yang ada. Satiadarma (2003: 119-120) menyatakan bahwa bahwa kemampuan berpikir yang dimiliki peserta didik dapat dikembangkan menggunakan teknik teknik belajar yang kreatif dan metode yang tepat, yaitu fungsi berpikir divergen harus diaktifkan dengan teknik-teknik belajar seperti teknik pemecahan masalah, gagasan, sumbang saran, dan daftar penulisan untuk merangsang peserta didik dalam berpikir divergen (berpikir dengan kemungkinan yang dilakukan) .

Data yang diperoleh dianalisis sehingga diperoleh hasil pada Tabel 1, diketahui bahwa peserta didik secara klasikal hasil belajarnya memperoleh ketuntasan pada aspek kognitif di siklus I, II, dan III sehingga dapat dikatakan telah tuntas $80 \%$ berdasarkan indikator keberhasilan serta persentase kemampuan bepikir kreatif peserta didik telah mencapai $75 \%$. Pencapaian hasil pembelajaran pada siklus I, II, dan III dikatakan berhasil sesuai yang diharapkan karena peserta didik telah memiliki keterbiasaan dibelajarkan model $P B L$. Sebagian besar peserta didik secara kelompok maupun kelas dapat berdiskusi secara baik. Hal tersebut didukung Anni (2009: 2-3) bahwa perubahan perilaku dapat dilakukan melalui belajar karena peserta didik memperoleh pengalam dari proses belajar itu. Munandar (2009: 109-110) menyatakan peningkatan kreativitas peserta didik dapat dilakukan di sekolah dengan memotivasi secara intrinsik peserta didik dan guru menggunakan 
prinsip mengajar dengan memberi dukungan kepada anak secara keseluruhan.

Ketuntasan kreatifitas berpikir dan peningkatan prestasi peserta didik dapat membuktikan bahwa dengan model $P B L$ dapat diterapkan sebagai alternatif model pembelajaran yang mampu melatih kreativitas peserta didik dari aspek pengetahuan yakni kecakapan dalam cara berpikir kreatif. Pernyataan sependapat dengan Mafune, guru dapat menggunakan model $P B L$ untuk melatih kreativitas peserta didik baik secara personal dan kelompok (Rusman, 2010: 222).

Pembimbingan peserta didik yang dilakukan oleh guru dalam mengatasi dan menyelesaikan masalah IPA berdasarkan linearitas langkalangkan dalam melakukan metode ilmiah. Kegiatan tersebut dilakukan agar peserta didik bisa mengatasi dan menyelesaikan masalah secara teratur dan tepat berdasarkan kaidah ilmiah dan sesuai dengan kaidah ilmiah. Torrance (Munandar, 2009: 21) juga berpendapat bahwa kreativitas pada pokoknya mirip dengan tahap metode ilmiah yaitu proses ilmiah dan kreatif dari mengutarakan masalah hingga diperoleh hasil. Dukungan dari guru juga dapat meningkatkan semangat peserta didik dalam menciptakan kreatifitas produkproduk karena menurut Munandar (2009: 46), jika peserta didik mempunyai kemampuan bakat dan diberi dukungan (eksternal maupun internal) untuk menyibukkan kreatifitas diri peserta didik sehingga menghasilkan kebermakanaan produkproduk.

\section{Simpulan}

Kemampuan berpikir kreatif peserta didik di MTsN 5 Kediri dapat meningkat karena pembelajaran diterapkan menggunakan model $P B L$.
Hal ini bisa ditunjukkan berdasarkan siklus II kemampuan berpikir peserta didik yang meningkat 3,3\% dan siklus III meningkat $3,8 \%$ serta pencapaian indikator siklus II dan III dikatakan berhasil. Hasil siklus I, II, dan III untuk rata-rata persentase kemampuan berpikir kreatif peserta didik yaitu $74,4 \%, 77,7 \%$, dan $81,5 \%$ sehingga dapat disimpulkan mengalami peningkatan. Hal ini ditunjukkan dengan persentase ketuntasan hasil belajar kognitif yang meningkat disetiap siklus dan indikator keberhasilan dapat dicapai. Dengan demikian data peningkatan persentase siklus II sejumlah 9,4\% dan siklus III meningkat $3,1 \%$ dengan kriteria peningkatan rendah.

\section{Daftar Pustaka}

Anni, Catharina Tri. 2009. Psikologi Belajar (Edisi Revisi).

Semarang: UNNES

Arends, R. 2007. Learning to Teach. Yogyakarta: Pustaka Pelajar.

Arifin, Z. 2013. Evaluasi Pembelajaran.

Bandung: PT Remaja

Rosdakarya

Arikunto, S. 2006. Prosedur Penelitian

Suatu Pendekatan Praktik

Praktik. Jakarta: PT Rineka

Cipta.

Arikunto, S., Suhardjono, dan Supardi.

2017. Penelitian Tindakan Kelas.

Jakarta: PT Bumi Aksara

Awang, H. \& I. Ramly. 2008. Creative

Thinking Skill Approach

Through Problem Based

Learning: Pedagogy and Practice in the Engineering classroom.

International Journal of Human

and Social Science, 3(1): 18-23.

Aziz et all. 2006. Penerapan Model

Pembelajaran Problem Based

Learning dengan Memanfaatkan

Alat Peraga Sains Fisika (Materi

Tata Surya) untuk Meningkatkan 
Hasil Belajar dan Bekerjasama Siswa. Jurnal Pendidikan Fisika Indonesia, 4(2): 94-99.

Diakidoy, I.A.N. \& C.P. Constantinou. 2001. Creativity in Physics: Response Fluency and Task Specificity. Creativity Research Journal, 13: 401-410.

Erpinah, I.. 2017. Pengaruh Model Problem Based Learning (PBL) terhadap Kemampuan Berpikir Kreatif Peserta didik pada Materi Interaksi Makhluk Hidup dan Lingkungan. Jurnal Skripsi Pendidikan Biologi

Huda, M.. 2013. Model-model Pengajaran dan Pembelajaran. Yogyakarta: Pustaka Pelajar

Irham, M. dan Wiyani, N. A.. Psikologi Pendidikan: Teori dan Aplikasi dalam Proses Pembelajaran. Jogjakarta: Ar-Ruzz Media.

Irwan, Z. D. 2011. Prinsip-Prinsip Ekologi Ekosistem, Lingkungan dan Pelestariannya. Jakarta: Bumi Aksara.

Kemendikbud. 2018. Ilmu Pengetahuan Alam SMP Kelas VII. Jakarta: Kemendikbud

Kristanto. 2013. Ekologi Industri. Yogjakarta: CV. Andi Offset.

Mulyasa. E. 2007. Kurikulum Tingkat Satuan Pendidikan Sebuah Pendekatan Praktis. Bandung: Remaja Rosdakarya.

Munandar, U. 2009. Pengembangan Kreativitas Anak Berbakat. Jakarta: Rineka Cipta.

Nugroho, G.A., Prayitno, B.A., dan Ariyanto, J.. 2017. Peningkatan Kemampuan Berpikir Kreatif Melalui Penerapan Project Based Learning pada Materi Pencemaran dan Daur Ulang Limbah. Jurnal Pembelajaran Biologi. Vol. 6, No 2, hal 9-12.

Purnamaningrum, A., Dwuastuti, S., Probosari, R.M., dan Noviawati.
2012. Peningkatan Kemampuan Berpikir Kreatif melalui Problem Based Learning (PBL) pada Pembelajaran Biologi Peserta didik Kelas x-10 SMA Negeri 3 Surakarta Tahun pelajaran 2011/2012. Jurnal Pendidikan Biologi. Vol. 4, No 3, hal 39-51

Rachman, Maman. 2008. Penelitian Tindakan Kelas (Dalam Bagian). Semarang: Universitas Negeri Semaran.

Silviani, R., Zubainur, C.M., dan Subianto, M.,. 2018. Kemampuan Berpikir Kreatif Peserta didik SMP melalui Model Problem Based Learning. Jurnal Didaktik Matematika. Vol. 5, No 1

Starr, C dkk. 2009. Biology The Unity and Divercity of Life. Jakarta: Salemba Teknika.

Satiadarma, M. 2003. Mendidik Kecerdasan. Jakarta: Pustaka Populer Obor.

Suparman dan Husen, Dwi Nastuti. 2015. Peningkatan Kemampuan Berpikir Kreatif Peserta didik melalui Penerapan Model Problem Based Learning. Jurnal Bioedukasi. Vol 3 No (2)

Suyono dan Hariyanto. 2015. Belajar dan Pembelajaran. Bandung: PT Remaja Rosdakarya.

Trianto. 2007. Model Pembelajaran Terpadu dalam Teori dan Praktek. Jakarta: Prestasi Pustaka Publisher

Trianto. 2007. Model-model Pembelajaran Inovatif Berorientasi Konstruktivistik. Jakarta: Prestasi Pustaka Publisher.

Wiyanto. 2008. Menyiapkan Guru Sains Mengembangkan Kompetensi Laboratorium. Semarang: UNNES PRESS.

Yatmono. 2015. Penerapan Model Pembelajaran Problem Based 
Learning untuk Meningkatkan Kemampuan Berpikir Kreatif Peserta didik X di SMA N 1 Semarang. Penelitian Tindakan Kelas. Semarang: Unnes. 